\title{
Body-weight regulation: causes of obesity
}

\author{
J. Alfredo Martinez \\ Department of Physiology and Nutrition, University of Navarra, 31008 Pamplona, Spain
}

\begin{abstract}
The aetiology and treatment of obesity have been fraught with disappointment for researchers, because the mechanisms that control fuel homeostasis and adiposity are incompletely understood. It is assumed that regulatory processes match the dietary fuel supply with energy requirements in order to maintain a stable body mass and adiposity. In this context several theories have been proposed to explain the laws of thermodynamics describing the conservation and transformation of energy in living organisms. In the light of new evidence it can now be hypothesized that the control of body weight and composition depends on an axis with three interrelated and selfcontrolled components: (1) food intake; (2) nutrient turnover and thermogenesis; (3) body fat stores. Complex feedback mechanisms underlie all these components. The major factors involved in obesity seem to be dietary and physical activity habits. These factors are affected by susceptibility genes that in turn may influence energy expenditure, fuel metabolism, muscle fibre function and appetite or food preferences. However, the increasing rates of obesity cannot be explained exclusively by changes in the gene pool, although genetic variants that were previously 'silent' are now being triggered by the high availability of energy- and fat-dense foods, and by the increasingly sedentary lifestyle of modern societies. The study of factors such as genetics and lifestyle implicated in weight gain and obesity is crucial for predictions about the future impact of the global epidemic of obesity, and provides a unique opportunity for the implementation of preventive action.
\end{abstract}

Obesity: Body-weight regulation: Lifestyle: Genetics

Weight and body energy content remain quite stable in most adult individuals for long periods of time (Jequier \& Tappy, 1999), despite daily fluctuations in energy balance (energy intake $v$. energy expenditure). It is assumed, therefore, that regulatory processes match the dietary fuel supply with energy requirements in order to maintain a stable body mass and adiposity (Weigle, 1994; Flatt, 1998; Schwartz et al. 1999). Thus, this lasting steady-state appears to involve a number of integrated mechanisms which contribute to the regulation of body weight and fuel stores (Rolls \& Hammer, 1995; Welle, 1995; Martinez \& Frühbeck, 1996; Hirsch et al. 1998; Tataranni, 1998). In this context, several theories and hypotheses have been proposed to explain the laws of thermodynamics describing the conservation and transformation of energy in living organisms (Seale, 1995; Heymsfield et al. 1995). Thus, the control of appetite as well as the stability of body composition have been explained by the occurrence of a physiological set point for body weight
(Bray 1987; Grundy, 1998), glucostatic or glycogenostatic controls for feeding (Flatt, 1995a; Astrup \& Raben, 1996; Stubbs, 1996), metabolic or nutrient-partitioning approaches (Bray, 1991a; Friedman, 1995; Flatt, 1996), the participation of the nervous system (Bray, 1991b; Saad et al. 1991; Kaiyala et al. 1995; Welle, 1995; Wurtman \& Wurtman, 1998), an adipostat mediated by signals from the adipose tissue (Friedman \& Halaas, 1998; Marti et al. 1999; Trayhurn et al. 1999), or by behavioural models (Blundell \& Macdiarmid, 1997). Furthermore, the description of mutations related to obesity and the identification of nutritional and transcription factors regulating adipocyte differentiation, or the pattern of gene expression affecting the lipid content in fat cells, constitute new breakthroughs in this area of research (Spiegelman \& Flier, 1996; Hwang et al. 1997; Margareto et al. 2000). Currently, it is assumed that the major factors involved in obesity are the genetic background and dietary and physical activity habits. 


\section{Body weight and fat regulation}

The precision of body-weight regulation (often within $\pm 1 \%$ over many years) requires a powerful slow feedback pathway controlling total fat mass (Schwartz \& Seeley, 1997). However, a sustained imbalance between the amount of energy consumed and the energy spent in everyday life certainly contributes to obesity onset (Stunkard, 1996; Aronne, 1998). Nevertheless, other factors such as the dietary macronutrient composition, the distribution of energy expenditure and individual substrate metabolism (Whitley et al. 1997; Silberbauer et al. 1998) influence the energy balance equation. In this context, it can be hypothesized that the control of body weight and composition depends on an axis with three interrelated and selfcontrolled components: (1) food intake; (2) nutrient turnover and thermogenesis; (3) body fat stores (Fig. 1). Complex feedback mechanisms underlie all three elements (Martinez \& Frühbeck, 1996). However, it should be assumed that body weight is ultimately determined by the interaction of genetic, environmental and psycho-social factors acting through several physiological mediators of food intake and energy expenditure (Jebb, 1997; Cooling et al. 1998; Weinsier et al. 1998).

\section{Food intake}

Food intake elicits distinct sensory inputs or circadian rhythms, gastrointestinal signals mediated by distention or local hormones, and nutrient signals, which modulate appetite through specific mechanisms involving different neurotransmitters (Bessesen \& Faggioni, 1998; Schwartz et al. 1999) including monoamines (noradrenaline, dopamine, serotonin etc.), amino acids (tryptophan, tyrosine, GABA etc.) and neuropeptides (orexins, melanocortins, pancreatic polypeptides, hormone-releasing factors, diverse gut-brain peptides such as cholecystokinin and neuropeptide $\mathrm{Y}$ etc.). The autonomic nervous system and several circulating hormones (insulin, cortisol, growth hormone etc.) are involved in the metabolic response to food intake (Macdonald, 1995; Astrup et al. 1996; Bjorntorp, 1998). All these signals, originating from food intake, generate neural as well as humoral outputs that trigger the appropriate quantitative and qualitative adjustments not only in nutrient intake, but also in energy and nutrient metabolism (Bray, 1991a; Horn et al 1999). Glucostatic, lipostatic and aminostatic theories appear to be sufficient to explain this regulatory process (Langhans, 1996; Stubbs, 1996).

\section{Nutrient turnover and thermogenesis}

A second loop would comprise the control of substrate cycling and thermogenesis, which not only depends on food supply, but also on specific mechanisms affecting the fuel mixture oxidized through efferent nervous, endocrine and enzymic regulatory phenomena (Martinez \& Frübheck, 1996; Jequier, 1998). The fat balance is poorly regulated as compared with protein or carbohydrate oxidation after food intake (Flatt, 1995b; Schutz, 1995a). The thermogenic response of brown adipose tissue (BAT) results from a balance between influences of central nervous system origin and the sympathetic innervation of BAT (Rothwell \& Stock, 1979). The outcome of this equilibrium has a direct influence on fat deposition as well as on food intake (Astrup, 1995; Macdonald, 1995).

\section{Body fat stores}

Maintenance of the fat balance has received far less attention, because the body fat stores are too large to be markedly affected by daily imbalances in energy intake. However, the recently discovered hormone leptin would cover the third regulatory system, a lipostat, which provides

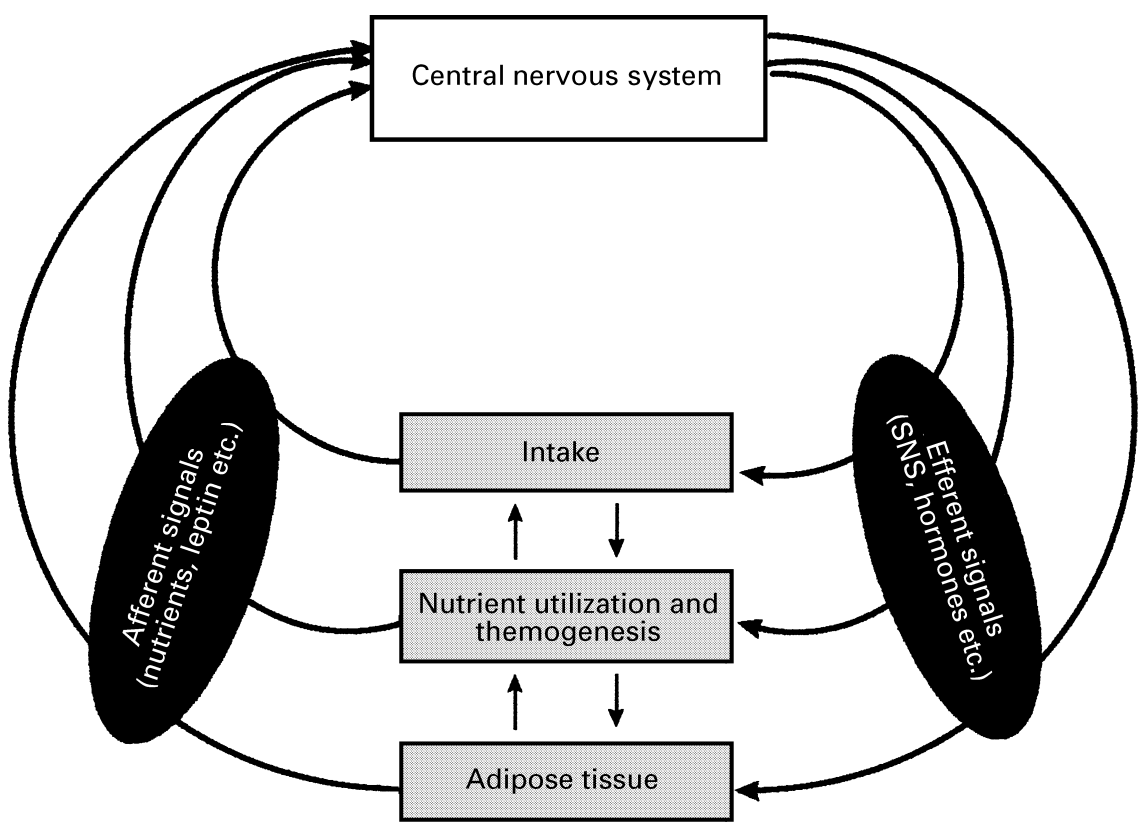

Fig. 1. Schematic representation of some mechanisms involved in body-weight and composition regulation. SNS, sympathetic nervous system. 
information about current stores to a central controller (Friedman \& Halaas, 1998), which in turn modulates fat deposition by triggering efferent nervous and endocrine signals mediated by $\beta_{3}$-adrenergic receptors (Flier \& Underhill, 1996) and some hormones or peptides with direct effects on lipid turnover, such as growth hormone, insulinlike growth factor-1, insulin and adrenal steroids (Bray, 1991a; Scott, 1996). Adiposity, in turn, may affect nutrient utilization and fuel selection directly or indirectly. The role of newly-discovered molecules and genes influencing adipocyte differentiation and fat deposition, such as peroxisome proliferator-activated receptors, CCAATenhancer binding protein, adipocyte fatty acid-binding protein etc., is under investigation (Spiegelman \& Flier, 1996; Berg, 1999; Margareto et al. 2000)

\section{Aetiology of obesity}

Obesity has been defined as excess fat deposition due to a chronic positive shift of the energy equation resulting from increases in energy input, decreases in energy output, or both (Bray, 1987). Obesity is also associated with other physiopathological conditions with high economic cost and health relevance (Aronne, 1998; Bjorntrop, 1998). Furthermore, the rapid increase in obesity rates over recent years suggests that cultural and societal influences, in addition to other physiopathological or genetic determinants, are affecting the adjustment in the energy balance equation. (Rosenbaum et al. 1997; Grundy, 1998). Thus, it is estimated that $40-70 \%$ of the variation in obesity-related phenotypes is heritable (Comuzzie \& Allison, 1998), while environmental influences may explain about $30 \%$ of the obesity cases (Hill, 1998). The great increase in the prevalence of obesity in populations whose gene pool has been relatively constant provides confirmation that environmental factors have considerable importance (Willett, 1998; Bray et al. 1998). The process of modernization and economic restructuring in both developing and developed countries has brought about a number of consequences affecting nutritional and physical activity patterns that contribute to the increasing rates of obesity (World Health Organization, 1998; Martinez-González et al. 1999). The food system has improved the availability of high-yielding energy foods, while the sedentary lifestyle with motorized transport and many labour-saving devices, as well as other physically-inactive pursuits (TV viewing, computer work etc.), have risen in recent decades (Williamson, 1996; Weinsier et al. 1998). On the other hand, cross-sectional data show a strong association between nutritional habits and physical inactivity and overweight and obesity, which could explain the increasing rates in some countries (Prentice \& Jebb, 1995; Dietz, 1996; Martinez et al. 1999). Furthermore, prospective studies provide additional evidence to suggest that a population increase in physical activity may help to prevent the growing prevalence of overweight and obesity over time (Surgeon General, 1996; Rippe \& Hess, 1998).

Since obesity rates are high (Institute of European Food Studies, 1998; Seidell, 1998), the continuous efforts made by the scientific community are warranted in order to further elucidate the origin and cause of obesity (Table 1), which involves neuroendocrine and genetic components, in addition to lifestyle factors (dietary and physical-activity patterns).

\section{Role of inheritance in obesity}

The role of a genetic predisposition to obesity has long been recognized to affect both terms (intake and expenditure) of the energy balance equation (Bray \& Bouchard, 1997). In this context evidence comes from human single gene mutations (leptin, leptin receptor, pro-opiomelanocortin, peroxisome proliferator-activated receptor- $\gamma$, melanocortin4 receptor, protein convertase 1 , and thyroid hormone receptor $\beta$ ), mendelian syndromes with obesity as a clinical feature (Prader-Willi, Wilson-Turner, Bordet-Bield etc.), animal models (transgenic animals, genetically-obese rodents or cross-breeding trials followed by quantitative screening of loci traits) and through association, casecontrol and linkage studies (nuclear families, twins and

Table 1. Factors involved in the cause of obesity and strategies of study

\begin{tabular}{|c|c|c|c|}
\hline Aetiological factors & Methods of studies & Evidence & References \\
\hline \multirow[t]{3}{*}{ Genetics } & Mendelian screening & + & Fauci et al. (1998), Farooqi et al. (1998), Perusse et al. (1999) \\
\hline & Animal models & + & Bray (1997), Hirsch \& Leibel (1998), West \& York (1998) \\
\hline & Association or linkage & $+/-$ & $\begin{array}{l}\text { Noble (1997), Sorensen et al. (1998), Chagnon et al. (1998), } \\
\text { Bouchard et al. (1998) }\end{array}$ \\
\hline \multirow[t]{3}{*}{ Diet or metabolism } & Epidemiological surveys & $?$ & $\begin{array}{l}\text { Lissner \& Heitmann (1995), Blundell \& Macdiarmid (1997), Willett } \\
\text { (1998), Seidell (1998), Bray \& Popkin (1998) }\end{array}$ \\
\hline & Intervention trials & + & $\begin{array}{l}\text { Schutz (1995ab), Schrauwen et al. (1997), Jequier (1998), Hirsch et al. } \\
\text { (1998), Prentice (1998), Labayen et al. (1999) }\end{array}$ \\
\hline & Animal models & + & Berraondo et al. (1997), Rothwell \& Stock (1979) \\
\hline \multirow[t]{2}{*}{ Physical activity } & Epidemiological surveys & + & $\begin{array}{l}\text { Surgeon General (1996), Williamson (1996), Saris (1998), Hills \& Byrne } \\
\text { (1998), Francis (1999), Martinez et al. (1999) }\end{array}$ \\
\hline & Intervention trials & + & $\begin{array}{l}\text { Tremblay \& Almeras (1996), Westerterp \& Goran (1997), Horton \& Hill } \\
\text { (1998), Weinsier et al. (1998), van Baak (1999), Tremblay et al. (1999) }\end{array}$ \\
\hline Gene-environment interactions & Case-control studies & + & $\begin{array}{l}\text { Heitmann et al. (1995, 1997), Astrup et al. (1996), Hill (1998), Beunen \& } \\
\text { Thomis (1999), Samaras et al. (1999) }\end{array}$ \\
\hline
\end{tabular}

+ Most existing scientific evidence is confirmatory; +/- depending on specific genes; ? controversial data relating to macronutrient distribution, but direct evidence after an excessive energy intake. 
adoption) with identification of candidate genes and genome-wide searches (Pi-Sunyer, 1997; West \& York, 1998; Sorensen et al. 1998; Noble, 1997; Farooqi et al. 1998; Perusse et al. 1999).

Genes may influence afferent and efferent signals as well as central mechanisms involved in body-weight regulation (Hirsch \& Leibel, 1998; Schanling, 1999). An update of the genetics of human obesity revealed that the numbers of genes or markers that have been linked with human obesity are increasing rapidly and now approach 200 (Bray et al. 1998; Perusse et al. 1999). Some genes, such as those involving uncoupling proteins, leptin and leptin receptor, $\beta_{2}$-adrenergic and $\beta_{3}$-receptors, peroxisome proliferatoractivated receptors, melanocortin-4 receptor, pro-opiomelanocortin etc., have been shown to be related to energy expenditure, and may be affected specifically by dietary intake and composition (Heitmann et al. 1995), and also by leisure-time physical activity (Heitmann et al. 1997). Thus, some genes are involved in food intake control (neuropeptide Y, leptin, pro-opiomelanocortin, cholecystokinin, melanin-concentrating hormone etc.) or the regulation of energy expenditure and thermogenesis $\left(\beta_{2^{-}}\right.$and $\beta_{3^{-}}$ adrenergic receptors, uncoupling proteins $1-3$, leptin etc.), while the expression of some others influence different signalling pathways, adipogenesis etc. (peroxisome proliferator-activated receptor, adipocyte fatty acid-binding protein, protein kinase A, CCAAT-enhancer binding protein etc.), affecting the energy equation (Bray \& Bouchard, 1997; Bray et al. 1998; Martinez, 1999).

The possible physiological mechanisms through which a genetic susceptibility may be operating include low resting metabolic rate, low rates of oxidation, low fat-free mass and altered food intake, as well as other factors related to macronutrient utilization, energy expenditure or the hormonal profile, including insulin sensitivity (Pi-Sunyer 1997; World Health Organization, 1998). The occurrence of genes or mutations responsible for the susceptibility of some individuals or groups of individuals to gain weight in the presence of an energy-dense diet or a reduced daily physical activity is being currently investigated (Hill \& Peters, 1998; Samaras et al. 1999).

Additive effects of mutations in the $\beta_{3}$-adrenergic receptor and uncoupling protein 1 genes on weight maintenance have been found (Fogelholm et al. 1998), which together with preliminary results from our department (MS Corbalán, A Marti and JA Martinez, unpublished results) reveal potential interactions between genes. Thus, obese individuals (average BMI approximately $40 \mathrm{~kg} / \mathrm{m}^{2}$ ) carrying the Trp64Arg mutation in the $\beta_{3^{-}}$ adrenergic receptor gene show a lower leptinaemia $(20 \cdot 5$ (SD 9.6) $\mathrm{ng} / \mathrm{ml}$ ) than obese controls without that mutation (33.0 (SD 6.3) ng/ml). Other evidence about the role of genes on obesity has been derived from an in vitro experiment in which transfer of the leptin gene into muscle increased lipolysis and $\mathrm{O}_{2}$ consumption in white adipose tissue in ob/ob (lacking leptin) mice (Marti et al. 1998), suggesting that obesity may benefit from gene therapy strategies.

Obesity is a complex syndrome with a multifactorial origin and may be explained by monogenic mutations, but in most cases it appears as a polygenic condition, which may be affected by a myriad of environmental influences (Bray et al. 1998).

\section{Dietary and metabolic factors}

Energy balance is determined by macronutrient intake, energy expenditure and partitioning in nutrient storage (Bray \& Bouchard, 1997). Thus, protein and carbohydrate intakes spontaneously elicit powerful autoregulatory adjustments in protein and carbohydrate oxidation, while the fat balance is less acutely regulated and more easily disrupted (Flatt, 1995b; Schutz, 1995b; Schrauwen et al. 1997).

On the other hand, most individuals reach a state of approximate weight maintenance in which the average composition of the fuels they oxidize matches the energy nutrient distribution in their diets (Burstein et al. 1996; Hirsch et al. 1998; Jequier \& Tappy, 1999). Nevertheless, under rigorously standardized conditions it was found that subjects tending to have high $24 \mathrm{~h}$ respiratory exchange ratio, i.e. those tending to burn more glucose but less fat, were at a higher risk of gaining weight during subsequent years (Schutz et al. 1989; Schutz, 1995b). The view that burning as much fat as that consumed is an important factor in avoiding obesity is further supported by the fact that adjustment of fat oxidation to match an increased fat intake occurs more slowly in obese subjects than in lean subjects (Horton et al. 1995; Astrup et al. 1996). Furthermore, it appears that individuals genetically predisposed to obesity are characterized by abnormal fat oxidation in a post-obese state (Nicklas et al. 1995; Lissner et al. 1997; Pagliassotti et al. 1997). Thus, the matching of the composition of the substrate mix oxidized to the macronutrient distribution in the diet may play a crucial role in enabling short-term weight stability (Proserpi et al. 1997; Jensen, 1998; Jequier \& Tappy, 1999).

Furthermore, weight gain may also depend on the distribution of dietary energy substrates, which have different impacts on metabolism and food intake, as well as on the sympathetic nervous system and, thereby, on energy balance and body weight (Prentice, 1998). Thus, short-term feeding of two formulas of different macronutrient composition, i.e. high-carbohydrate and high-fat meals, to healthy volunteers produced higher values for glucose oxidation, thermic effect of feeding and heart rate (as an indicator of sympathetic activation) in those individuals receiving the high-carbohydrate challenge as compared with the fat-rich formula (Labayen et al. 1999). However, when a similar dietary intervention was carried out in obese individuals the results seem to indicate that these individuals were less efficient at oxidizing fat intake, while highcarbohydrate feeding was accompanied by an increase in 'de novo' lipogenesis (Marques-Lopes et al. 2000). Furthermore, a relatively high respiratory exchange ratio may reflect reduced fat oxidation, which has been suggested as a possible predictor of weight gain (Schutz, 1995b; Weinsier et al. 1998), although other investigators (Flatt \& Guptta, 1999) have reported that such metabolic efficiency plays a minor role in the development or avoidance of obesity.

Much controversy exists about the influence of dietary fat on the prevalence of obesity (Willett, 1998; Bray \& Popkin, 
1998; Astrup, 1999). Thus, arguments often presented against an important involvement of dietary fat in obesity onset are based on observational longitudinal and ecological studies, which suggest that reductions in fat consumption and the frequent use of low-energy food products in some countries have been associated with a paradoxical increase in the prevalence of obesity (Heini \& Weinsier, 1997; Lawton, 1998; Willett, 1998). Furthermore, although lowfat isoenergetic diets may be helpful in decreasing body fatness or preventing weight gain (Astrup, 1999; Kendall et al. 1991), current scientific evidence seems to indicate that dietary fat reduction should be seen mainly as a means of reducing the dietary energy density (Lissner \& Heitmann, 1995; Grundy, 1998). On the other hand, experimental trials in which animals were fed on a high-fat diet have consistently shown a gradual weight gain (Berraondo et al. 1997), while passive over-consumption and obesity have been seen in human subjects on fat-rich energy-dense diets (Blundell et al. 1995; Blundell \& Macdiarmid, 1997). Furthermore, populations consuming very-low-fat diets usually do not show high rates of obesity prevalence (Paeratakul et al. 1998), while a meta-analysis of intervention studies has revealed that in free-living subjects an appreciable, although often short lived, weight loss occurs in individuals who reduce their fat consumption (Bray \& Popkin, 1998; Lissner, 1999). Research into the role of carbohydrate or sugar intake in the prevalence of obesity, as assessed through epidemiological and laboratory studies, has revealed that groups consuming the highest proportion of energy as sugars are less likely to be obese than low sugar consumers, which has been explained by reciprocal changes in fat intake, and effectiveness in relation to body-weight regulation (Prentice \& Jebb, 1995). Some of these results may be explained by confounding or modifying factors such as genetic predisposition, sex and physical activity (Lissner \& Heitmann, 1995; Astrup et al. 1996).

\section{Physical activity}

Three major components of energy expenditure that may influence body weight and composition (Tremblay \& Almeras, 1996; Westerterp \& Goran, 1997) have been identified: BMR; thermic effect of food; energetic cost of physical activity (Rising et al. 1994; De Jonge \& Bray 1997; Thielecke et al. 1997). Thus, most available evidence suggests that a lower activity-related energy expenditure is an important contributor to the increasing prevalence of obesity, although a blunted response to food intake and reductions in resting energy expenditure may have an impact on weight gain (Albo et al. 1997; Weinsier et al. 1998). Furthermore, cross-sectional data have often found associations between leisure-time physical activity (inverse) or total amount of time spent sitting down (direct) and BMI (Martinez-González et al. 1999), while a low participation in sports activities, a lack of interest in taking exercise (precontemplation) and a high number of hours spent sitting down at work are statistically significant predictors of obesity (sports activities $P<0.0005$, no sports $P<0.001$, sitting $P<0.004$; Martinez et al. 1999). An analysis of time-budget surveys revealed that the time required for earning a living and for domestic work has declined appreciably over recent decades, and has been accompanied by a weak yet statistically significant increase in BMI for men but not for women (Ferro-Luzzi \& Martino, 1996).

In this context, calculations concerning the introduction of labour-saving gadgets between the 1950s and the 1990s has meant that men and women now participate in much less exercise that they did a generation ago (World Health Organization, 1998). Thus, playing requires approximately $3762 \mathrm{~kJ}(900 \mathrm{kcal}) / 4 \mathrm{~h}$ and TV viewing uses up $1296 \mathrm{~kJ}$ $(310 \mathrm{kcal}) / 4 \mathrm{~h}$, shopping in the high street uses $10455 \mathrm{~kJ}$ $(2500 \mathrm{kcal}) /$ week and supermarket shopping with a trolley and car uses less than $418 \mathrm{~kJ}(100 \mathrm{kcal}) /$ week, mowing the lawn by hand uses up to $2091 \mathrm{~kJ}(500 \mathrm{kcal}) / \mathrm{h}$ whereas using an electric mower requires only $753 \mathrm{~kJ}(180 \mathrm{kcal}) / \mathrm{h}$, making a bed with blankets uses $2405 \mathrm{~kJ}(575 \mathrm{kcal}) /$ week and plumping a duvet uses less than $1255 \mathrm{~kJ}(300 \mathrm{kcal}) /$ week, making up coal fires uses $47300 \mathrm{~kJ}(11300 \mathrm{kcal}) /$ week and lighting a gas fire only a few $\mathrm{kJ}$, washing clothes by hand uses $6273 \mathrm{~kJ}(1500 \mathrm{kcal}) / \mathrm{d}$ while using a machine-washing requires only $1129 \mathrm{~kJ}(270 \mathrm{kcal}) / 2 \mathrm{~h}$, driving a car with power steering reduces the energy needed to steer by about $84 \mathrm{~kJ}(20 \mathrm{kcal}) / \mathrm{h}$, etc. (G Golberg, personal communication). In fact, fewer occupations would now be classified as very active as compared with several decades ago (World Health Organization, 1996). These data, however, do not offer an explanation for possible cause or effect relationships between the inverse association of BMI and physical activity, making it difficult to establish whether obese individuals are less active because of their obesity or whether a low level of activity caused the obesity (World Health Organization, 1998; Pasman et al. 1999).

Valuable information about trends in energy expenditure, which shows that the increased prevalence of obesity seems to parallel a reduction in physical activity patterns and a rise in sedentary behaviours in various populations (Surgeon General, 1996; Johansson et al. 1999), is only available from the 1980s (Weinsier et al. 1998). Thus, the First National Health and Nutrition Examination Survey carried out between 1971 and 1984 in 8300 individuals showed that low levels of physical activity in the intervening 10-year period were associated with weight gains, and recreational activities were inversely correlated with body weight (Williamson et al. 1993). Also, in a follow-up study on 5200 Finnish subjects the regression analysis showed that men and women with no regular weekly exercise had a higher odds ratio (about 2.6) for clinically-significant body mass gain in comparison with the most active groups (Haapanen et al. 1997). Other studies and surveys using indirect indicators of physical activity such as TV viewing (Coakley et al. 1998; Dietz, 1996), number of cars per household (Prentice \& Jebb, 1995) and number of hours sitting down during leisure time, or leisure-time physical activity (Martinez-González et al. 1999) are consistent with the view that a reduction in energy expenditure may be a major determinant of the current epidemic of obesity (Heini \& Weinsier, 1997; Willett, 1998).

The interactions between heredity and sedentariness have been assessed using twin pairs, and it was concluded that the genetic background may modify the effect of physical activity on weight change in males (Heitmann et al. 1997) and females (Samaras et al. 1999), and that lifestyle may 
have an obesity-promoting effect, depending on a genetic predisposition (Hill, 1998; Hill \& Peters, 1998).

\section{Conclusion}

The high precision of body-weight regulation is achieved by a number of integrated homeostatic systems which adjust or match the energy balance constituents (energy intake $v$. energy expenditure). The physiological consequence of this complex machinery is to minimize excessive body-weight gain or loss, and represents an advantage during human evolution for survival in periods of affluence or famine. In this context, three main factors appear to participate in body-weight maintenance: metabolic utilization of nutrients, dietary habits and physical activity. These factors are affected by susceptibility genes which in turn may influence energy expenditure, fuel metabolism, muscle fibre function and appetite or food preferences. However, the increasing rates of obesity cannot be exclusively explained by changes in the genetic pool, although genetic variants that were previously 'silent' are now triggered by the high availability of energy- and fat-dense foods and by the increasingly sedentary lifestyle of modern societies.

Genotype-environment interactions arise when the response of a phenotype (e.g. fat mass) to environmental changes depends on the genotype of the individual. Although it is well known that there are inter-individual differences in the responses to various dietary interventions, very few attempts have been made to determine whether these differences are genotype-dependent. Furthermore, the genotype-environment influences may affect body weight, energy expenditure, and body fatness induced by overeating or by consuming diets with a relatively high fat content, supporting the view that genetic traits may increase the risk of developing obesity by affecting the regulation of macronutrient oxidation.

In this context, current epidemiological trends in weightfor-height measurements indicate that a major cause of the global obesity problem lies in dietary and physical activity patterns, while genetic and metabolic studies reveal that there are individuals who are more susceptible to weight gain than others. Effective prevention and management of obesity requires an integrated approach, with intervention across different segments of the population through adequate information. The examination of factors such as genetics and lifestyle implicated in weight gain and obesity is crucial for predictions about the future impact of the global epidemic of obesity, and provides a unique opportunity for the implementation of preventive action.

\section{References}

Albo J, Shor M, Curi M, Murphy L, Heymsfield SB \& Pi-Sunyer FX (1997) Resting metabolic rate in obese women. American Journal of Clinical Nutrition 66, 531-538.

Aronne LJ (1998) Obesity. Medical Clinics of North America 82, $161-181$.

Astrup A (1999) Dietary fat and obesity. Scandinavian Journal of Nutrition 34, 285-295.

Astrup A (1995) The sympathetic nervous system as a target for intervention in obesity. International Journal of Obesity 19, S24-S28.
Astrup A, Buemann B, Toubro S \& Raben A (1996) Defects in substrate oxidation involved in the predisposition to obesity. Proceedings of the Nutrition Society 55, 817-828.

Astrup A \& Raben A (1996) Glucostatic control of intake and obesity. Proceedings of the Nutrition Society 55, 485-495.

Berg JP (1999) Pluripotent PPAR $\gamma$ polymorphisms. European Journal of Endocrinology 140, 293-295.

Berraondo B, Bonafonte A, Fernández-Otero MP \& Martinez JA (1997) Effects on energy utilization of a $\beta_{3}$-adrenergic agonist in rats fed on a cafeteria diet. Eating Weight Disorders 2, 130-137.

Bessesen DH \& Faggioni R (1998) Recently identified peptides involved in the regulation of body weight. Seminars in Oncology 25, 28-32.

Beunen G \& Thomis M (1999) Genetic determinants of sport participation and daily physical activity. International Journal of Obesity 23, S55-S63.

Bjorntorp P (1998) Obesity: a chronic disease with alarming prevalence and consequences. Journal of Internal Medicine 244, 267-269.

Blundell JE \& Macdiarmid JI (1997) Passive overconsumption. Fat intake and short-term energy balance. Annals of the New York Academy of Sciences 827, 392-407.

Blundell JE, Cotton JR, Delargy H, Green S, Greenough A, King NA \& Lawton CL (1995) The fat paradox: fat-induced satiety signals versus high fat overconsumption. International Journal of Obesity 19, 832-825.

Bouchard C, Pérusse L, Rice T \& Rao DC (1998) The genetics of human obesity. In Handbook of Obesity, pp. 157-190 [GA Bray, C Bouchard and WPT James, editors]. New York: Marcel Dekker Inc.

Bray GA (1987) Obesity: a disease of nutrient or energy balance? Nutrition Reviews 45, 33-43.

Bray GA (1991a) Treatment for obesity: a nutrient balance/nutrient partition approach. Nutrition Reviews 49, 33-45.

Bray GA (1991b) Obesity, a disorder of nutrient partitioning: the MONA LISA hypothesis. Journal of Nutrition 121, 1146-1162.

Bray GA (1997) Progress in understanding the genetics of obesity. Journal of Nutrition 127, 940S-942S.

Bray GA \& Bouchard C (1997) Genetics of human obesity: research directions. FASEB Journal 11, 937-945.

Bray GA, Bouchard C \& James WPT (editors) (1998) Textbook of Obesity. New York: Marcel Dekker Inc.

Bray GA \& Popkin BM (1998) Dietary fat intake does affect obesity! American Journal of Clinical Nutrition 68, 1157-1173.

Burstein R, Prentice AM, Goldberg GR, Murgatroyd PR, Harding M \& Coward WA (1996) Metabolic fuel utilisation in obese women before and after weight loss. International Journal of Obesity 20, 253-259.

Chagnon Y, Perusse L \& Bouchard C (1998) The human obesity gene map: the 1997 update.Obesity Research 6, 76-92.

Coakley EH, Rimm EB, Colditz G, Kawachi I \& Willett W (1998) Predictors of weight change in men: results from the Health Professionals Follow-up Study. International Journal of Obesity 22, 89-96.

Comuzzie AG \& Allison DB (1998) The search for human obesity genes. Science 280, 1374-1377.

Cooling J, Barth J \& Blundell J (1998) The high-fat phenotype: is leptin involved in the adaptive response to a high fat (high energy) diet? International Journal of Obesity 22, 1132-1135.

De Jonge L \& Bray GA (1997) The thermic effect of food and obesity: a critical review. Obesity Research 5, 622-631.

Dietz WH (1996) The role of lifestyle in health: the epidemiology and consequences of inactivity. Proceedings of the Nutrition Society 55, 829-840.

Farooqi S, Rau H, Whitehead J \& O'Rahilly S (1998) ob gene mutations and human obesity. Proceedings of the Nutrition Society 57, 471-475. 
Fauci AS, Braunwald E, Isselbacher KJ, Wilson JD, Martin JB, Kasper DL, Hauser SL \& Longo DL (1998) Harrison's Principles of Internal Medicine. New York: McGraw-Hill.

Ferro-Luzzi A \& Martino L (1996) Obesity and physical activity. Ciba Foundation Symposia 20, 207-221.

Flatt JP (1995a) Body composition, respiratory quotient, and weight maintenance. American Journal of Clinical Nutrition 62, 1107S-1117S.

Flatt JP (1995b) Diet, lifestyle, and weight maintenance. American Journal of Clinical Nutrition 62, 820-836.

Flatt JP (1996) Carbohydrate balance and body-weight regulation. Proceedings of the Nutrition Society 55, 449-465.

Flatt JP (1998) What do we most need to learn about food intake regulation? Obesity Research 6, 307-310.

Flatt JP \& Guptta SK (1999) Stature, fat free-mass, resting energy expenditure and obesity. Scandinavian Journal of Nutrition 34, $40 \mathrm{~S}$.

Flier JS \& Underhill L (1996) Adrenergic receptors: concepts and clinical implications. New England Journal of Medicine 334, 580-585.

Fogelholm M, Valve R, Kukkonen-Harjula K, Nenonen A, Hakkarainen V, Laakso M \& Uusitupa M (1998) Additive effects of the mutations in the $\beta_{3}$-adrenergic receptor and UCP-1 genes on weight loss and weight maintenance in Finnish women. Journal of Clinical Endocrinology and Metabolism 83, 4246-4250.

Francis KT (1999) Status of the year 2000 health goals for physical activity and fitness. Physiological Therapy 79, 405-414.

Friedman JM \& Halaas JL (1998) Leptin and the regulation of body weight in mammals. Nature 395, 763-770.

Friedman MI (1995) Control of energy intake by energy metabolism. American Journal of Clinical Nutrition 62, 1096S-1100S.

Grundy SM (1998) Multifactorial causation of obesity: implications for prevention. American Journal of Clinical Nutrition 67, 563S-572S.

Haapanen N, Miilunpalo S, Pasanen M, Oja P \& Vuori I (1997) Association between leisure time physical activity and 10-year body mass change among working-aged men and women. International Journal of Obesity 21, 288-296.

Heini AF \& Weinsier RL (1997) Divergent trends in obesity and fat intake patterns: the American paradox. American Journal of Medicine 102, 259-264.

Heitmann BL, Kaprio J, Harris JR, Rissanen A, Korkeila M \& Koskenvuo M (1997) Are genetic determinants of weight gain modified by leisure-time physical activity? A prospective study of Finnish twins. American Journal of Clinical Nutrition 66, 672-678.

Heitmann BL, Lissner L, Sorensen TI \& Bengtsson C (1995) Dietary fat intake and weight gain in women genetically predisposed for obesity. American Journal of Clinical Nutrition 61, 1213-1217.

Heymsfield SB, Darby PC, Muhlheim LS, Gallagher D, Wolper C \& Allison DB (1995) The calorie: myth, measurement, and reality. American Journal of Clinical Nutrition 62, 1034S-1041S.

Hill JO (1998) Genetic and environmental contributions to obesity. American Journal of Clinical Nutrition 68, 991-992.

Hill JO \& Peters JC (1998) Environmental contributions to the obesity epidemic. Science 280, 1371-1374.

Hills AP \& Byrne NM (1998) Exercise prescription for weight management. Proceedings of the Nutrition Society 57, 93-103.

Hirsch J, Hudgins LC, Leibel RL \& Rosenbaum M (1998) Diet composition and energy balance in humans. American Journal of Clinical Nutrition 67, 551S-555S.
Hirsch J \& Leibel RL (1998) The genetics of obesity. Hospital Practice 33, 55-75.

Horn CC, Addis A \& Friedman MI (1999) Neural substrate for an integrated metabolic control of feeding behavior. American Journal of Physiology 276, R113-R119.

Horton TJ, Drougas H, Brachey A, Reed GW, Peters JC \& Hill JO (1995) Fat and carbohydrate overfeeding in humans: different effects on energy storage. American Journal of Clinical Nutrition 62, 19-29.

Horton TJ \& Hill JO (1998) Exercise and obesity. Proceedings of the Nutrition Society 57, 85-91.

Hwang CS, Loftus TM, Mandrop S \& Lane MD (1997) Adipocyte differentiation and leptin. Annual Review of Cellular and Developmental Biology 13, 231-259.

Institute of European Food Studies (1998) IEFS Report. A Pan-EU Survey on Consumer Attitudes to Physical Activity, Body Weight and Health. Luxembourg: European Commission Directorate V/F.3.

Jebb SA (1997) Aetiology of obesity. British Medical Bulletin 53, 264-285.

Jensen MD (1998) Diet effects on fatty acid metabolism in lean and obese humans. American Journal of Clinical Nutrition, 531S-534S.

Jequier E (1998) Effect of lipid oxidation on glucose utilization in humans. American Journal of Clinical Nutrition 67, 527S-530S.

Jequier E \& Tappy L (1999) Regulation of body weight in humans. Physiological Reviews 79, 451-480.

Johansson L, Thelle DS, Solvoll K, Bjørneboe G-EAa \& Drevon CA (1999) Healthy dietary habits in relation to social determinants and lifestyle factors. British Journal of Nutrition 81, 211-220.

Kaiyala KJ, Woods SC \& Schwartz MW (1995) New model for the regulation of energy balance and adiposity by the central nervous system. American Journal of Clinical Nutrition 62, 1123S-1134S.

Kendall A, Levitsky DA, Strupp BJ \& Lissner L (1991) Weight loss on a low-fat diet: consequence of the imprecision of the control of food intake in humans. American Journal of Clinical Nutrition 53, 1124-1129.

Labayen I, Forga L \& Martinez JA (1999) Nutrient, oxidation and metabolic rate as affected by meals containing different proportions of carbohydrate and fat, in healthy young women. European Journal of Nutrition 38, 158-166.

Langhans W (1996) Metabolic and glucostatic control of feeding. Proceedings of the Nutrition Society 55, 97-515.

Lawton CL (1998) Regulation of energy and fat intakes and body weight: the role of fat substitutes. British Journal of Nutrition $\mathbf{8 0}$, $3-4$.

Lissner L (1999) Dietary fat and prevention of obesity. Scandinavian Journal of Nutrition 34, 185S.

Lissner L \& Heitmann BL (1995) Dietary fat and obesity: evidence from epidemiology. European Journal of Clinical Nutrition 49, 79-90.

Lissner L, Heitmann BL \& Bengtsson C (1997) Low-fat diets may prevent weight gain in sedentary women: prospective observations from the population study of women in Gothenburg, Sweden. Obesity Research 5, 43-48.

Macdonald IA (1995) Advances in our understanding of the role of the sympathetic nervous system in obesity. International Journal of Obesity 19, S2-S7.

Margareto J, Corbalán M, Marti A \& Martinez JA (2000) Timedependent regulation of some white adipose tissue genes involved in adipogenesis and in thermogenesis after cafeteria feeding. Proceedings of the Nutrition Society 59, 110A.

Marques-Lopes I, Ansorena D, Forga L, Astiasarán I \& Martínez JA (2000) Short-term metabolic changes and de novo lipogenesis 
induced by a high-carbohydrate meal in lean and obese subjects. Proceedings of the Nutrition Society 59, 125A.

Marti A, Berraondo B \& Martínez JA (1999) Leptin: Physiological actions. Journal of Physiology and Biochemistry 55, 43-50.

Marti A, Novo FJ, Martinez-Anso E, Zaratiegui M, Aguado M \& Martinez JA (1998) Leptin gene transfer into muscle increases lipolysis and oxygen consumption in white fat tissue in $o b / o b$ mice. Biochemical and Biophysical Research Communications 246, 859-862.

Martinez JA (2000) Determinantes geneticos de la obesidad (Genetic determinants of obesity). In Genètica de la Obesidad (Genetics of Obesity). [J. Braguinski, editor]. Buenos Aires: Interamericana (In the Press).

Martinez JA \& Frühbeck G (1996) Regulation of energy balance and adiposity: a model with new approaches. Journal of Physiology and Biochemistry 52, 255-258.

Martinez JA, Kearney JM, Kafatos A, Paquet \& Martinez-González MA (1999) Variables independently associated with selfreported obesity in the European Union. Public Health Nutrition 2, 125-133.

Martinez-González MA, Martinez JA, Hu FB, Gibney MJ \& Kearney J (1999) Physical inactivity, sedentarism lifestyle and obesity in the European Union. International Journal of Obesity 23, 1192-1201.

Nicklas BJ, Goldberg AP, Bunyard LB \& Poehlman ET (1995) Visceral adiposity is associated with increased lipid oxidation in obese, postmenopausal women. American Journal of Clinical Nutrition 62, 918-922.

Noble RE (1997) The incidence of parental obesity in overweight individuals. International Journal of Eating Disorders 22, 265-271.

Paeratakul S, Popkin BM, Keyou G, Adair LS \& Stevens J (1998) Changes in diet and physical activity affect the body mass index of Chinese adults. International Journal of Obesity 22, 424-431.

Pagliassotti MJ, Gayles EC \& Hill JO (1997) Fat and energy balance. Annals of the New York Academy of Sciences 827, 431-448.

Pasman WJ, Saris WHM \& Westerterp-Platenga MS (1999) Predictions of weight maintenance. Obesity Research 7, 60-69.

Perusse L, Chagnon YC, Weisnagel J \& Bouchard C (1999) The human obesity gene map: the 1998 update. Obesity Research 7, 111-129.

Pi-Sunyer FX (1997) Energy balance: role of genetics and activity. Annals of the New York Academy of Sciences 819, 29-36.

Prentice AM (1998) Manipulation of dietary fat and energy density and subsequent effects on substrate flux and food intake. American Journal of Clinical Nutrition 67, 535S-541S.

Prentice AM \& Jebb SA (1995) Obesity in Britain: gluttony or sloth? British Medical Journal 311, 437-439.

Proserpi C, Sparti A, Schutz Y, Di-Vetta V, Milon H \& Jequier E (1997) Ad libitum intake of a high-carbohydrate or high-fat diet in young men: effects on nutrient balances. American Journal of Clinical Nutrition 66, 539-545.

Rippe JM \& Hess S (1998) The role of physical activity in the prevention and management of obesity. Journal of the American Dietetic Association 98, S31-S38.

Rising R, Harper IT, Fontvielle AM, Ferraro RT, Spraul M \& Ravussin E (1994) Determinants of total daily energy expenditure: variability in physical activity. American Journal of Clinical Nutrition 59, 800-804.

Rolls BJ \& Hammer VA (1995) Fat, carbohydrate, and the regulation of energy intake. American Journal of Clinical Nutrition 62, 1086S-1095S.

Rosenbaum M, Leibel LR \& Hirst J (1997) Obesity. New England Journal Medicine 337, 396-407.

Rothwell NJ \& Stock MJ (1979) A role for brown adipose tissue in diet-induced thermogenesis. Nature 281, 31-35.
Saad MF, Alger SA, Zurlo F, Young JB, Bogardus C \& Ravussin E (1991) Ethnic differences in sympathetic nervous systemmediated energy expenditure. American Journal of Physiology 261, E789-E794.

Samaras K, Kelly PJ, Chiano MN, Spector TD \& Campbell LV (1999) Genetic and environmental influences on total-body and central abdominal fat: the effect of physical activity in female twins. Annals of Internal Medicine 130, 873-882.

Saris WH (1998) Fit, fat and fat free: the metabolic aspects of weight control. International Journal of Obesity 22, S15-S21.

Schanling M (1999) Genes and obesity. Journal of Internal Medicine 245, 611-667.

Schrauwen P, van-Marken-Lichtenbelt WD, Saris WH \& Westerterp KR (1997) Changes in fat oxidation in response to a high-fat diet. American Journal of Clinical Nutrition 66, 276-282.

Schutz Y (1995a) Macronutrients and energy balance in obesity. Metabolism 44, 7-11.

Schutz Y (1995b) Abnormalities of fuel utilization as predisposing to the development of obesity in humans. Obesity Research $\mathbf{3}$, 173S-178S.

Schutz Y, Flatt JP \& Jequier E (1989) Failure of dietary fat intake to promote fat oxidation: a factor favoring the development of obesity. American Journal of Clinical Nutrition 50, 307-314.

Schwartz MW \& Seeley RJ (1997) The new biology of body weight regulation. Journal of the American Dietetic Association 97, $54-58$.

Schwartz MW, Baskin DG, Kaiyala KJ \& Woods SC (1999) Model for the regulation of energy balance and adiposity by the central nervous system. American Journal of Clinical Nutrition 69, $584-596$.

Scott J (1996) New chapter for the fat controller. Nature 379, $113-114$

Seale JL (1995) Energy expenditure measurements in relation to energy requirements. American Journal of Clinical Nutrition 62, 1042S-1046S.

Seidell JC (1998) Dietary fat and obesity: an epidemiologic perspective. American Journal of Clinical Nutrition 67, 546S-550S.

Silberbauer CJ, Jacober B \& Langhans W (1998) Dietary fat level and short-term effects of a high-fat meal on food intake and metabolism. Annals of Nutrition and Metabolism 42, 75-89.

Sorensen TI, Holst C \& Stunkard AJ (1998) Adoption study of environmental modifications of the genetic influences on obesity. International Journal of Obesity 22, 73-81.

Spiegelman BM \& Flier JS (1996) Adipogenesis and obesity: rounding out the big picture. Cell 87, 377-389.

Stubbs RJ (1996) Dietary macronutrients and glucostatic control of feeding. Proceedings of the Nutrition Society 55, 467-483.

Stunkard AJ (1996) Current views on obesity. American Journal of Medicine 100, 230-236.

Surgeon General (1996) Surgeon General's report addressing physical activity and health. Nutrition Reviews 54, 280-284.

Tataranni PA (1998) From physiology to neuroendocrinology: a reappraisal of risk factors of body weight gain in humans. Diabetes and Metabolism 24, 108-115.

Thielecke F, Moseneder J, Kroke A, Klipstein-Grobusch K, Boeing H \& Noack R (1997) Determination of total energy expenditure, resting metabolic rate and physical activity in lean and overweight people. Zeitschrift für Ernahrungswissenschaft 36, 310-312.

Trayhurn P, Hoggard N, Mercer JG \& Rayner DV (1999) Leptin: Fundamental aspects. International Journal of Obesity 23, 22-28.

Tremblay A \& Almeras N (1996) Physical activity, macronutrient balance and body weight control. In Progress in Obesity 
Research, pp. 207-212 [A Ángel, H Anderson, C Bouchard, D Lau, L Leiter and R Mendelson, editors]. New York: Libbey \& Co.

Tremblay A, Doucet E \& Imbeault P (1999) Physical activity and weight maintenance. International Journal of Obesity 23, S50-S54.

van Baak MA (1999) Exercise training and substrate utilisation in obesity. International Journal of Obesity 23, S11-S17.

Weigle DS (1994) Appetite and the regulation of body composition. FASEB Journal 8, 302-310.

Weinsier RL, Hunter GR, Heini AF, Goran MI \& Sell SM (1998) The etiology of obesity: relative contribution of metabolic factors, diet, \& physical activity. American Journal of Medicine 105, 145-150.

Welle S (1995) Sympathetic nervous system response to intake. American Journal of Clinical Nutrition 62, 1118S$1122 \mathrm{~S}$.

West DB \& York B (1998) Dietary fat, genetic predisposition, and obesity: lessons from animal models. American Journal of Clinical Nutrition 67, 505S-512S.
Westerterp KR \& Goran MI (1997) Relationship between physical activity related energy expenditure and body composition: a gender difference. International Journal of Obesity 21, 184-188.

Whitley HA, Humphreys SM, Samra JS, Campbell IT, Maclaren DP, Reilly T \& Frayn KN (1997) Metabolic responses to isoenergetic meals containing different proportions of carbohydrate and fat. British Journal of Nutrition 78, 15-26.

Willett WC (1998) Is dietary fat a major determinant of body fat? American Journal of Clinical Nutrition 67, 556S-562S.

Williamson DF (1996) Dietary intake and physical activity as 'predictors' of weight gain in observational, prospective studies of adults. Nutrition Reviews 54, S101-S109.

Williamson DF, Madans J, Anda RF, Kleinman JC, Kahn HS \& Byers T (1993) Recreational physical activity and ten-year weight change in a US national cohort. International Journal of Obesity 17, 279-286.

World Health Organization (1998) Obesity. Preventing and Managing the Global Epidemic. Report of a World Health Organization Consultation on Obesity. Geneva: WHO.

Wurtman RJ \& Wurtman JJ (1998) Serotoninergic mechanism and obesity. Journal of Nutritional Biochemistry 9, 511-515. 